\author{
Аманбекова Н.Д. ${ }^{1}$ \\ ${ }^{l}$ Қазақ инноваџиялық гуманитарлық-заң университеті PhD докторанты \\ (Семей к.., Қазақ̧стан)

\section{ШЫҒЫС ҚАЗАҚСТАННЫН ШАҒЫН ҚАЛАЛАРЫНЫН КЕНЕСТІК КЕЗЕНДЕГІ ТАРИХИ БАСТАУЛАРЫ МЕН ДАМУЫНЫН АЛҒЫШАРТТАРЫ}

\begin{abstract}
Аңцатпа
Мақалада Шығыс Қазақстанның Аягөз, Зайсан, Шар, Шемонаиха, Зыряновск, Курчатов, Риддер, Серебрянск шағын қалаларының тарихы мен аймақ өңіріндегі осы қалалардың әлеуметтік -экономикалық жағдайына әсері тарихи тұрғыда зерттелген. Сонымен қатар Кеңестік дәуірдегі Шығыс Қазақстандағы моноқалаларының әлеуметтік- экономикалық жай-күйіне талдау жасау арқылы, моноқалалардың өнеркәсіптік өндірісінің тиімділігін айқындалды. Мақала барысында аймақтағы шағын қалалар тарихының ақтандақ беттерінің толысуына, сондай-ақ ұзақ мерзімдегі тоталитарлық жүйе кезеңіндегі шағын қалалардың маңызын тарихи тұрғыдан жеткізуге талпыныс жасалды.

Риддер, Зырян, Серебрянск және Курчатов моноқалалары басым өнеркәсіп салалары бағытында қарастырылған. Шығыс Қазақстан облысы моноқалаларның кеңестік дәуірдегі экономикалық мүмкіндіктерін көрсететін деректерге мән берілді.

Шығыс Қазақстандағы шағын қалалардың қалыптасуы және дамуы өнеркәсіптің базалық салаларының ерекшелігін қалыптастырудың шешуші әсері арқылы жүргендігі басты назарда сипатталды.

Тірек сөздер: Шығыс Қазақстан, Аягөз, Зайсан, Шар, Шемонаиха, Зыряновск, Курчатов, Риддер, Серебрянск, шағын қалалар тарихы, әлеуметтік -экономикалық жағдай, өндіріс орындары.
\end{abstract}

AmanbekovaN.D.

Kazakh Innovative University of Humanities and LawPhD student, (Semey, Kazakhstan)

\title{
HISTORICAL ORIGINS AND PREREQUISITES FOR THE DEVELOPMENT OF SMALL TOWNS IN EAST KAZAKHSTAN DURING THE SOVIET PERIOD
}

\section{Abstract}

The article historically studied the history of small towns in East Kazakhstan Ayagoz, Zaysan, Shar, Shemonaikha, Zyryanovsk, Kurchatov, Ridder, Serebryansk and the impact of these cities on the socio-economic situation in the region. In addition, by analyzing the socio - economic state of single - industry towns in East Kazakhstan in Soviet times, their industrial production efficiency was determined. The article attempts to fill in the empty pages of the history of small towns in the region, as well as to historically convey the significance of small towns during the period of a long totalitarian system.

The priority industries are monotowns Ridder, Zyryanovsk, Serebryansk and Kurchatov. Significance was attached to the data reflecting the economic opportunities of single-industry towns of the East Kazakhstan region in Soviet times.

In the center of attention, it was noted that the formation and development of small towns in East Kazakhstan took place through the decisive influence of the formation of the specifics of the basic industries.

Key words: East Kazakhstan, Ayagoz, Zaisan, Shar, Shemonaikha, Zyryanovsk, Kurchatov, Ridder, Serebryansk, history of small towns, socio-economic situation, places of production.

$$
\text { Аманбекова Н.Д. }{ }^{1}
$$

Казахский гуманитарно-юридический инноваџионный университет, PhD докторант, (2. Семей, Казахстан) 


\section{ВОСТОЧНОГО КАЗАХСТАНА В СОВЕТСКИЙ ПЕРИОД}

\section{Аннотащия}

В статье исторически изучена история малых городов Восточного Казахстана Аягоз, Зайсан, Шар, Шемонаиха, Зыряновск, Курчатов, Риддер, Серебрянск и влияние этих городов на социально -экономическое положение региона. Кроме того, путем анализа социально - экономического состояния моногородов Восточного Казахстана в советское время была определена их эффективность промышленного производства. В статье были предприняты попытки заполнить пустые страницы истории малых городов региона, а также к исторической передаче значения малых городов в период длительного тоталитарного строя.

Приоритетными отраслями промышленности предусмотрены моногорода Риддер, Зыряновск, Серебрянск и Курчатов. Было придано значение данным отражающим экономические возможности моногородов ВосточноКазахстанской области в советское время.

В центре внимания было отмечено, что формирование и развитие малых городов в Восточном Казахстане происходило через решающее влияние формирования специфики базовых отраслей промышленности.

Ключевые слова: Восточный Казахстан, Аягоз, Зайсан, Шар, Шемонаиха, Зыряновск, Курчатов, Риддер, Серебрянск, история малых городов, социально -экономическое положение, места производства.

Шағын қалалардың тарихына жүгінсек Кеңес дәуірінде Қазақстанда сандық жағынан басқа қалалық қоныстардан едәуір басым болатын шағын қалаларды дамытуға басым орын берілді. Мұндай Қазақстандағы шағын қалалардың қалыптасуы мен дамуы республиканың социалистік жаңғыруы ерекшелігінің, өнеркәсіптің базалық салаларының қалыптасуының шешуші ықпалында болғандығымен байланысты.

Қазақстанда шағын қалалардың қарқынмен дамуы өнеркәсіптік және ауыл шаруашылығы бағытын игерумен тікелей байланысты. Бұл қалаларда Қазақстанның экономикасында өнеркәсіп саласының, әсіресе қара және түсті металлургияның, отын, химия және мұнай-химия өнеркәсібінің, электр энергетикасының үлес салмағы жоғары болды. Сонымен қатар, жекелеген қалалар немесе қалалардың жекелеген топтары Қазақстанда өндірілген белгілі бір өнімнің жартысынан көбін берді. Алайда, Одақтың ыдырауымен, нарықтық қатынастарға көшумен Қазақстанның шағын қалаларының экономикасы көп жағдайда өз маңызын жоғалтты, олардың көпшілігі құлдырауға кетті және іс жүзінде жойылу қаупінде тұрған еді.

Соған қарамастан, шағын қалалар мен олардың тұрғындары дағдарыс құбылыстарына қарамастан, елдегі әлеуметтік-экономикалық процестерде маңызды рөл атқаруды жалғастыруда және көп жағдайда бүкіл қазақстандық қоғамның даму үрдістері мен бағыттарын дәл солар айқындайды. Сондықтан Қазақстанның шығысында орналасқан шағын қалаларының әлеуметтік-экономикалық даму проблемаларын кеңестік кезең тұрғысынан зерттеу тұтастай алғанда қоғамның даму дәрежесін бағалауға, оның проблемалық мәселелерін анықтауға және одан әрі перспективаларды белгілеуге мүмкіндік береді[1].

Осы тақырыптың қоғадық сұраныс тұрғысынан туындағанын Қазақстан Республикасының 2004-2006 жылдарға арналған шағын қалаларды дамыту бағдарламасынан көре аламыз. Қазақстан Республикасының 20042006 жылдарға арналған шағын қалаларды дамыту бағдарламасы Қазақстан Республикасы Үкіметінің 2003 жылы 5 қыркүйектегі №903 «2004-2006 жылдарға арналған Қазақстан Республикасы Үкіметінің Бағдарламасын жүзеге асыру іс шараларының жоспары туралы» қаулысына сәйкес әзірленді. Шағын қалаларды дамытудың негізгі бағыттары: экономика құрылымын әртараптандыру жолымен жетілдіру және көлемі әртүрлі және салалық қажетті заттары бар кәсіпорындарды оңтайлы ұштастыру арқылы құру; қалалардың функционалдық мамандану құрамын кеңейту; жақын маңдағы шағын қалалардың минералдық шикізат ресурстарын игеру; халыққа көрсетілетін негізгі қызметтің қолжетімділігін арттыру үшін аумақтық ұйымдастырудың әлеуметтік инфрақұрылымын қолдану; кадрлық әлеует пен халықтың ұдайы өсуі; шағын кәсіпкерлік субъектілерді инфрақұрылымның аумақтық ұйымымен қолдау. Шағын қалаларды дамытудың негізгі бағыттары минералды шикізаттық, өндірістік және еңбек әлеуеті, қолайлы географиялық жағдайын ескере отырып анықталды. Республиканың шағын қалаларына жаңа өмір беру үшін және, ең бастысы, арнайы мемлекеттік оңалту және дамыту бағдарламасы. Мұндай бағдарламаны әзірлеу тек объективті және жан-жақты талдау негізінде мүмкін шағын қалалардың әлеуметтік-экономикалық тарихы, олардың экономикасы мен әлеуметтік-мәдени саласының инфрақұрылымын қалыптастыру.

Өткен онжылдықтардағы Шығыс Қазақстанның шағын қалаларының дамуын мұндай ретроспективті талдау шағын қалалардағы қазіргі күрделі әлеуметтік-экономикалық, мәдени және демографиялық жағдайдың тамыры мен бастауын көруге мүмкіндік береді. Тақырыпты зерттеудің өзектілігі сонымен қатар қазіргі заманғы әлеуметтік-экономикалық, мәдени мәселелерді шешу үшін шағын қалалар тұрғындарының санындағы, әлеуметтік, ұлттық, білім беру құрылымдарындағы өткен өзгерістерді ғылыми негізделген бағалау қажеттілігі болып табылады.

Шығыс Қазақстанда шағын қалалардың қалыптасуы мен дамуы өнеркәсіптің базалық салаларының қалыптасу ерекшеліктерінің шешуші әсерінен болды. Қазақстан өңірлерінің өнеркәсіптік игерілуінің әсерінен қала қоныстарының құрылымы тарихи қалыптасқан, негізінен саны 20 мыңға дейінгі шағын қалалардан тұрады, мысалы, Қазақстанда 1959 жылғы Бүкілодақтық халық санағы бойынша 43 қаланың 25-інде халық саны 50 мың адамнан аспады, оларда қала халқының 15\% - ы және бүкіл халықтың 7\% - ы тұрды. 1989 жылғы Бүкілодақтық халық санағы бойынша мұндай қалалардың 51-і 84-і болды. Шығыс Қазақстан облысы бойынша шағын қалаларға негізінен зерттеліп отырған кезеңде Аякөз, Зайсан, Зыряновск, Курчатов, Серебрянск, Шар, 
Шемонаиха, Риддер қалалары. Енді қалалардың тарихи негізне тоқтала кетейік. 1928 жылы Бұқтырма уезі Зырян болысының біраз жері мен Бұқтырма, Өскемен уезінің біраздаған жерін қосып Зырян ауданы құрылды. Орталығы Зырян селосы болып бекіді. 1932 жылы Зырян ауданы Шығыс Қазақстан облысының құрамына енді. 1941 жылдан аудан орталығы Зырян селосына қалалық статус берілді.

1957 жылы Зырян ауданы бірінші рет таратылды. Ал 1963 жылы Зырян селолық аудан ретінде қайта қалпына келтіріліп, 1964 жылы «селолық» деген сөз алынып тасталды. 1965 жылы 10 желтоқсанда аудан екінші мәрте таратылып, 1977 жылы қайтадан қалпына келтірілді. Парыгино селосы аудан орталығы болып бекітілді. 2012 жылдың мамыр айында Елбасы шағын қалаларды дамытудың 2012-2020 жылдарға арналған бағдарламасын қабылдады. Серебрянск, Зырян қалалары Қазақстан Республикасы Экономикалық даму және сауда министрлігі шешімімен Шығыс Қазақстандағы шағын қалаларды дамыту тізіміне енді. Зырян ауданы тек қазба байлықтарымен ғана емес, сонымен қатар өз ісінің шебері тамаша еңбек адамдарымен де мақтана алады.

Социалистік Еңбек Ері, тау-кен ісінің маманы - Н.Қ. Жақсыбаев, республикаға танымал совхоз директорлары П.Т. Полянский, П.Ф. Дягилев, Кеңес Одағының батыры П. Кольцов (танымал есім), бұрынғы облыс әкімі В. Метте (танымал есім), Қазақстан Жазушылар Одағының мүшесі, ақын А. Тасқараұлы осы Зырян ауданының тумалары. Зырян-1941 жылдан бастап Шығыс Қазақстан облысындағы облыстық бағыныстағы қала, темір жол станциясы. Кенді Алтайдың орталық бөлігінде, Ертіс пен Бұқтырма өзендерінің аралығында орналасқан. 1987 жылға халық саны 54,5 мың адамды құрады, Ұлы Отан соғысы жылдарында Зырян қорғаныс кәсіпорындарын қорғасынмен және басқа түсті металдармен үздіксіз жабдықтады. 80-ші жылдары Зырян республиканың түсті металлургия орталықтарының біріне айналды. Қалада ірі өнеркәсіптік кәсіпорындар орналасқан: Зырян полиметалл комбинаты, Зырян қорғасын комбинаты. КСРО-ның 60 жылдығы; сондай-ақ, ет комбинаты, тігін фабрикасы және сүт зауыты бар. Серебрянск - Зырян аймағындағы, Ертіс өзенінің оң жағалауымен созылып жатқан қала. ОлБұқтырма су электрстанциясының бас бөгетіненалысемесжердеорналасқан. Серебрянск Өскеменге автомобиль, теміржолжәне су көлігіменбайланысты, оларданқала 90 шақырымқашықтықтаорналасқан. Облысорталығы Зырян қаласы 120 шақырымжерде. Серебрянск - Бұқтырма су электрстанциясынақызметететінқала.Қалаорнындағыелдімекен Новоалександровка шағынауылыболды. Су электрстанциясыныңқұрылысыбасталған 1950 жылдарданбастапол тез жұмысшыауылға, оданкейінқалағаайналды $(1962$ жылдан)

Қаладасоныменқатарқорғанысмақсатындатынысалудыңжекежәнеұжымдыққорғанысыншығаратынбейорганикал ықөндірісбойынша Серебрянск зауытысалынды. Бұлкәсіпорын КСРО-ныңқұлауыментоқырауғаұшырады. Жергіліктіәскерибөлім

бастықасбеттіңдоғасығанақалғанмәдениорталықсияқтыкейбірнысандардыңбасынакүнтуды.

Серебрянскініңшеттеріәдемікөріністерге толы. Жағажайлар мен Ертісжағалауытанымалдемалысорындарыболыптабылады[2].

Аягөз-Семей облысының Аягөз ауданындағы қала (1939 жылдан), әкімшілік орталығы (1928 жылдан), ірі темір жол станциясы. Қала Нарын өзенінің Аягөз өзеніне құятын жерінде орналасқан. 1931 жылы негізі қаланған Түрксіб құрылысы мен пайдалануға берілуі Аякөздің экономикалық дамуына үлкен өзгеріс әкелді. 1985 жылы қалада автожөндеу және темірбетон бұйымдары зауыттары, ет комбинаты, май зауыты, элеватор және т.б. кәсіпорындар жұмыс істеді. [3, б. 185].

Аягөз ауданы 1928 жылы құрылды. Әкімшілік орталығы Аягөз қала мәртебесін 1939 жылы алды. Ауданның жалпы жер көлемі 5 млн. гектар құрайды. Осылайша Аягөз жер көлемі жөнінен республика бойынша Қарағанды облысының Арал аудандарынан кейін үшінші орын алады.

1930 жылы қазіргі Аягөз қаласы орналасқан жерден Түркістан-Сібір теміржолы өтіп, Аягөз станциясының ірге тасы қаланды. Осылайша мұнда алғашқы паровоз депосы және басқа теміржолға қатысты кәсіпорындар бой көтерді. Сол тұста көптеген Аягөздіктер теміржол құрылысына белсене қатысыты. Сол жылы аудан орталығы Сергиопольден Аягөз станциясына көшірілді.

Аягөзге теміржолдың бір тармағының тартылуы ғасырлар бойы мүлгіген далаға тың лебі әкелді. Сондай сілікініс пен оянуда аяулы азаматтардың бас көтеруі заңды нәрсе. Олардың ішінде Т.Рысқұлов пен М.Тынышбаевтың есімін ерекше атап өткен жөн.

Түрксіб жобасын жасау үшін Үкімет тарапынан арнайы мемекеттік комиссия құрылды. Оның құрамында әр ұлттың өкілдері енгізілді. 1930 жылы 1 мамыр күні Аягөз паровоз депосы пайдалануға берілді.

Ауданның ауыл шаруашылығның тарихы 1920-1930 жылдардағы алғашқы мойынсеріктер мен ұжымдық шаруашылықтардан басталып, МТС-тар құрыла бастады.

Ауданның ауыл шарушылығы саласында көптеген кадрлар өсіп жетілді. Аудан мәдениеті мен өнерінде кезінде елді мекендерде құрылған қызыл отаулар мен автоклубтар аса маңызды орын алды. Олар жергілікті жерлердегі өнерпаздар өнерін ұштауға, жұртшылық арасында оларды кеңінен насихаттауға жол ашты.

Ауданда балалар және жасөспірімдер спорт мектебі, «Ринг» спорт қоғамы жұмыс істейді. Ауданның шығармашылық қауымының бірден-бір тоқайласар орыны жергілікті баспасөз екендігі белгілі. Ауданда 1930 жылы 4 қазанда «Жаңа ауыл» газетінің алғашқы саны жарық көрді.

1996 жылдың наурызынан бастап «Аягөз жаңалықтары» тәуелсіз қоғамдық - саяси газеті шығып келеді.

Аудан тарихында қоғамдық тәртіпті сақтау ешқашан назардан тыс қалған емес. Бұл әсіресе еліміз егемендігін алған күннен бастап ерекше назарда. Еліміздің шығыс шекарасын күзетуде Аягөз әскери гарнизонының рөлі мен маңызы өте ерекше. Гарнизон жауынгерлері өздерінің әскери-оку жаттығуларын жүзеге асыра отырып, аудан ұжымдарымен, оқу орындарымен тығыз байланыс жасап келеді[4]. 
Кеңес заманында Курчатовты географиялық карталарда көру мүмкін болмады. Бұл құпия қала, оның атластарында Семейден Конечная станциясымен (қазіргі Дегелең деп аталады) шығатын тұйық теміржол желісі болған.

Қалаға кірудің қатаң бақылауы орнатылған, ал тікенекті сымдар елді мекеннің периметрі бойынша созылған. Бұл Курчатовтың Семей ядролық полигонының технологиялық орталығы болғандығына байланысты. Қала физик Игорь Курчатовтың атымен аталады, ол «ұлттық ядролық бомбаның атасы» саналды., ол арнайы сынақтар мен іс -сапарлары мен кезінде осында жиі болатын. Курчатов 1947 жылы алғашқы кеңестік ядролық бомбаның полигонынан 45 шақырым жерде - Семей полигонының солтүстік шекарасында құрылды. 1949 жылдан бастап қала мәртебесіне ие болды. КСРО ыдырағаннан кейін Курчатов қаласының тұрғындары әскери нысандардың жабылуына байланысты едәуір азайды. Жақсы өмір сүру үшін көптеген әскери және ғалымдар бұрынғы жабық қаладан кетіп қалды. Қазіргі кезде бес қабатты ғимараттардың барлық блоктары бос, ақырзаманнан кейінгі пейзажға ұқсайды. Кеңестік дәуірде үкімет Курчатовтың ғылыми-техникалық әлеуетін жандандыруға тырысуда. Қалада бірнеше ядролардан тұратын ұлттық ядролық орталық бар (геология, ядролық физика, атом энергиясы саласындағы зерттеулер). Ядролық орталық қазір Курчатовтың негізгі кәсіпорны болып табылады.

Қаланың келбеті 1950-1980 жылдардағы кеңестік қаланың әдеттегі типтік бір сарынды тұрпатта салынған. Орталық алаңда қаланың «өкіл әкесі» саналаған Игорь Курчатовтың ескерткіші орнатылған. Төбесінде жер астында ядролық сынақтар жүргізілгендігімен белгілі аласа таулы Дегелең (полигон аумағында таралған) бар. Полигон 1991 жылы жабылғанына қарамастан, Дегелең аумағы, полигонның басқа бөліктері сияқты, радиоактивті фонға байланысты қорғалған[5].

Шар қаласы Қазақстанның шығысында орналасқан, бұл республиканың маңызды көлік торабы және теміржолдағы шанышқы. Оның аумағы аттас өзеннің жағалауын бойлай созылып жатыр. Қала тарихының басталуына дейін Түрксіб станциясының құрылысы басталды, оның қасында кейін қалаға айналған шағын қала өсіп шықты. Ол өз атауын Ертіске дейін жеткізетін Шар өзенінің құрметіне алды. Ескі күндері өзен артериясында осындай күш болды, оның бағыты наймандарды жеңгеннен кейін өз арнасынан өткен моңғол әскерінің үштен бірін лезде алып кетті. Топонимнің шығу тегі бірнеше нұсқаға ие. Олардың біреуінің айтуынша, бұл атау «жылу» сөзімен байланысты, бұл қазақ тілінен аударғанда үзіліс дегенді білдіреді. Тағы бір нұсқа бойынша, Шыңғысхан мен оның әскері осы аймақтан өткенде, оған жердің түсі әсер етіп, оны Шар деп атаған, ол «сары» дегенді білдіреді. Енді қазіргі заманғы қала жылдың кез-келген уақытында ауданның ерекше түсімен ерекшеленеді. Бұған қала айналасында өсетін ши шөптері себеп болды деп есептеледі. Қала аумағына 4 аудан кіреді. Ежелгісі Шанхай, Шар өзенінің жағасында қазақтың ауыл ретінде құрылған. «Шанхай» атауы ежелгі қазақша «Шаңқай» сөзіне қатысты, яғни «күндізгі он екіде» дегенді білдіреді деп есептеледі. Мұның түсіндірмесі бар. Шахай ауданы қаланың күн түске жақын өтетін жерінде орналасқан. Кеңес Одағы ыдырағаннан кейін қала тұрғындарының саны шамамен екі есеге азайды. Олардың бір бөлігі Ресейге, екіншілері шет елдерге кетті. Келесі қысқарту Шар бұрынғы мәртебесін жоғалтқан сәтте болды. Жұмыссыздық деңгейінің жоғарылауы да осыған байланысты. Қаланы тірілту үшін билік ол арқылы су арналарын жүргізіп, цемент зауытын салып, мектепті жөндеді. Музыкалық продюсер Бари Алибасов, Қазақстанның халық ақыны Төлеу Көбдіков, генерал Бариан Тұрсынов, орыс сәулетшісі Трюго Бардт сияқты атақты адамдар Шар қаласында дүниеге келген. Шар - 1963 жылдан бастап қала, 1972 жылдан бастап әкімшілік орталық. 1927 жылы Түрксіб құрылысына байланысты теміржол станциясы және жұмысшы кенті ретінде құрылды. Қалада 80-жылдардың ортасында локомотив депосы, галантерея фабрикасы, жөндеу шеберханалары, баспахана, автокөлік кәсіпорындары және астық қабылдау пункттері жұмыс істеді. [3, б. 479].

Зайсан жері дарындылардан ешқашан кенде болмаған. Бізде ел басқарған Халит, Бұтабай, Зейнолла, Ақбай тәрізді болыстар, Шұлғаубайдай шешен, Бұланбайдай палуан, Қоңыр, Ақыштай қажылар, елді аузына қаратқан билер шыққан. Жыр алыбы Жамбылдың өзі Шөжемен қатар қойған Ноғайбай ақындыМәскеу университетінің профессоры Ивановский бүкіл Ресейге әйгілеп, талантына тәнті еткен. Ал, бүгіндер Зайсан тумалары Есет, Әубәкір, Тоқтарбек, Ұлықбек, Асқар, Нұрлан, Марат, Кәдірбек, Гүлнәр, Советхандар қазақ әдебиетінің алғы легінде тұр[6].

Аудан өміріндегі ең ауыр және жауапты болған кезең - Ұлы Отан соғысы жылдары болды. Майданға - 6569 және еңбек армиясына - 1099 зайсандықтар аттанған. 2595 адам майданда қаза болды. Полковник В.Е.Головченко Кеңес Одағының Батыры атағын алса, сержант Манап Әубәкіров Даңқ орденінің толық иегері болды.

Зайсан - Ресей мен Қытай арасын жалғастыратын алтын көпір болған ұлы керуен жолы. Қазақстан Республикасының тәуелсіздік алуымен елімізде кеден қызметі жолға қойылған. 1992 жылдың мамыр айынан бастап, Шығыс аймақтық кеденіне қарасты «Майқапшағай» кеден бекеті құрылды. Сондай-ақ, 2006 жылдың сәуір айынан бастап, «Майқапшағай-Жеменей» шекара сауда орталығы ашылған.

Шемонаиха қаласы - Шығыс Қазақстан облысының солтүстігіндегі аудан орталығы. Ол Алтайдың бөктеріндегі Убаның (Ертістің саласы) солтүстік (оң) жағасында жатыр. Қалада Қазақстан-Ресей шекарасына дейінгі соңғы теміржол вокзалы бар, сондықтан мұнда шекара бекеті орналасқан. Шемонаиха - қазақ Алтайының алғашқы қоныстарының бірі. Ол 18 ғасырдың ортасынан бастап Шемонаевское ауылы деп аталған. Ауыл Томск губерниясының Змиевск ауданына қарасты және оны осы Ресейден келген қашқын шаруалар мекендеді, олар крепостнойлық пен шіркеу езгісінен осы алыс және шалғай жерлерде жасырынды. Шемонаиханың негізін қалаушылар 17 ғасырдың соңында осында қоныстанған Польшадан келген иммигранттар болып саналады. 
Ауылда қашқын адамдар көп болғандықтан, мұнда жаңадан келгендерге көмектесу дәстүрі пайда болды. Түнде әр үйдің астында тамақ қалды.

Шемонаиха тарихында өсудің екі кезеңі атап өтілді. Біріншісі 19 ғасырдың аяғында, крепостнойлық құқық жойылғаннан кейін болды - бұл жерге елдің еуропалық провинцияларынан шаруалар күштеп қоныстандырылды. Екіншісі 1950 жылдардың аяғында, мыс кен орнын игеру және мыс химия зауытының құрылысы басталған кезде болды (1962 жылы іске қосылды). Содан кейін Шемонаиха қаласында Убу арқылы өтетін көпір және алғашқы көп қабатты үйлер пайда болды. 1961 жылы Шемонаиха қала болды. Қазіргі кезде елді мекен бірнеше карьерлермен қоршалған, бірақ сонымен бірге қала өзінің ірі сүт өндірісімен танымал.

Шемонайханың әйгілі тумасы - жазушы Анатолий Иванов, «Көлеңкелер түсте жоғалады» және «Мәңгілік шақыру» романдарының авторы. 2009 жылы өзеннің үстіндегі қияға оның шығармашылығына әйел бейнесіндегі ескерткіш орнатылды. Жергілікті жердегі тағы бір көрнекті орын - 2004 жылы киелі ағашқа айналған шіркеу.

Риддер кеніші ауылға, кейінірек елді мекенге айналады және 1932 жылдың 1 қаңтарынан бастап Риддер қаласына айналды.

Ұлы Отан соғысы басталғанға дейін оның атауы Лениногорск болып өзгертілді. Кеңес кезеңінде қалада бірқатар өнеркәсіптік кәсіпорындар, тұрғын үйлер мен инфрақұрылым нысандары салынды. Алғашқы түсті металлургия кәсіпорыны қорғасын зауыты болды.

Қала аумағында 1935 жылы Ермаков негізін қалаған ботаникалық бақ бар. 1992 жылы Батыс Алтай табиғи қорығы құрылды. Риддер экономикасы әр түрлі меншік формасындағы өнеркәсіптік кәсіпорындарға, оның ішінде ірі және кіші компанияларға, дүкендерге, дәріханаларға, жанармай құю бекеттеріне, базарларға, кафелерге негізделген. Қалада дамыған инфрақұрылым бар. Жол жабыны жүйелі түрде қалпына келтірілуде, байланыс жүйелерінің алдын алу, көшелер мен алаңдар абаттандырылуда. Мәдени-ағарту ұйымдары, атап айтқанда Мәдениет сарайы мен кітапханалар белсенді жұмыс істейді. «Дауыстар», «Аребеск» сынды шығармашылық шеберлік топтарымен танымал. Тарихи-өлкетану мұражайында қала мен оның айналасы туралы көптеген экспонаттар жинақталған[7].

Шығыс Қазақстанда урбандалу деңгейі ең жоғары деңгейдің бірі болды, бұл ретте жаңа қалалардың пайда болуының неғұрлым жоғары қарқыны онда жаңғырту кезеңінде келді. Зерттеу кезеңінде қалалық типтегі елді мекендер желісінің одан әрі дамуы болды. 1959 жылы Шығыс Қазақстанда алты қала болды-Өскемен, Лениногор, Зырян, Зайсан, Семей және Аягөз. Біз көріп отырғанымыздай, Шығыс Қазақстанда жаңа қалалық қоныстардың құрылуы бұрынғысынша табиғи-минералды ресурстарды өнеркәсіптік игерумен байланысты болды [8].

Қалалық елді мекендер санының үштен бір бөлігі кен орындары мен пайдалы қазбалар кен орындарында пайда болған жұмысшы ауылдар болды. Олардың арасында темір кені өнеркәсібінің орталығы Шығыс Қазақстанда - Рудный кентін айтамыз.

XX ғасырдың тоқсаныншы жылдарында шағын қалалардың халқы күрт азайды[9]. Шығыс Қазақстанда да осы мәселе орын алды. 1989-1999 жылдар аралығында Курчатов қаласы - 43\%-ын жоғалтты. Халық саны бойынша 13 шағын қала қала мәртебесіне сәйкес келмейді, соның ішінде Шығыс Қазақстан облысы бойынша Курчатов, Шарск [9].

а) өндіру өнеркәсібі басым дамыған қалалар-15 қала:

* металл кендерін өндіру-Рудный, Зырян, шикізат ресурстарының басқа түрлерін өндіру - Жаңатас, Қаратау, Жітіқара.

в) Ауыл шаруашылығы өнімдерін қайта өңдейтін салалар басым дамыған қалалар - 19 қала: Шемонаиха, Зайсан, Электр энергиясын өндіру салалары басым дамыған қалалар - Серебрянск.

2. Өнеркәсіптік - көлік орталықтары-8 қала: Аягөз, Шар,

3. Ғылыми - тәжірибелік орталықтар-Курчатов,

4. Курорттық қалалар-Сарыағаш, Щучинск, Қарқаралы.

5. Бұрынғы өнеркәсіптік және өнеркәсіптік емес функцияларын біртіндеп Жоғалтатын қалалар-4 қала: Жем, Темір, Державинск, Текелі, Форт-Шевченко, Қазалы.

3. 19 шағын қала ауылдық аудандардың орталықтары болып табылмайды: Степногорск, Темір, Ембі, Жем, Қапшағай, Текелі, Шар, Серебрянск, Курчатов, Шу, Шахтинск, Саран, Приозерск, Қаражал, Лисаковск, Арқалық, Ақсу, Қазалы, Жаңаөзен. Олардың бір бөлігі облыстық маңызы бар қалалар болып табылады, бір бөлігі аудандардың қосылуы нәтижесінде аудан орталықтары мәртебесін жоғалтты.

Қазақстанның ерекшеліктерінің бірі шағын қалалардың ел аумағы бойынша біркелкі бөлінбеуі болып табылады [10].

Шығыс Қазақстанда XX ғасырдың 60-жылдары құрылыс және құрылыс индустриясында, ауыл шаруашылығы салаларында, қайта өңдеу өнеркәсібінде жұмыс істейтіндердің үлесі айтарлықтай өсті, бұл осы қалаларды жеткілікті дамыған әлеуметтік инфрақұрылымы бар ауданаралық агроиндустриялық орталықтарға жылжытуға әкелді. Бұған мысал-Шығыс Қазақстан облысының Шемонаиха қаласы, оның қалалық қоныстары негізінен түсті металдарды өндіруге және өңдеуге маманданған. Олардың маңызды ерекшелігі жеткілікті түрде дамыған әлеуметтік құрылым болып табылады, ол іргелес аудандардың аса бай рекреациялық ресурстарымен (көлдер, өзендер) ұштастыра отырып, қалалардың қала құраушы дерекқорын рекреациялық орталықтар ретінде дамыту мүмкіндігін ашады, мысалы, Шар қаласы.

Шығыс Қазақстандағы шағын қалалардың әлеуметтік-тұрмыстық инфрақұрылымын дамытудың бұрын қол жеткізілген белгілі бір деңгейі қазіргі уақытта айтарлықтай бұзылған. Бұрынғы КСРО аймақтары арасындағы 
ондаған жылдар бойғы экономикалық байланыстардың үзілуімен, экономиканың күрт құлдырауымен, қала құрушы кәсіпорындардың консервациясы мен жабылуымен көптеген шағын қалалар елеске айналды, ал олардың халқы оларды жаппай тастап кетеді немесе өмір сүрудің төменгі деңгейде тұр.

Соған қарамастан, Шығыс Қазақстандағы шағын қалалар мен олардың тұрғындары дағдарыс құбылыстарына қарамастан, елдегі әлеуметтік-экономикалық процестерде маңызды рөл атқаруды жалғастыруда және көп жағдайда бүкіл қазақстандық қоғамның даму үрдістері мен бағыттарын солар айқындайды. Сондықтан Шығыс Қазақстанның шағын қалаларының әлеуметтік-экономикалық даму проблемаларын зерттеу тұтастай алғанда аймақтағы қоғамның даму дәрежесін бағалауға, оның проблемалық мәселелерін анықтауға және одан әрі болашағын белгілеуге мүмкіндік береді.

Республиканың шағын қалаларына жаңа өмір беру үшін ең бастысы шараның бірі арнайы мемлекет тарапынан оларды оңалту және дамыту бағдарламасын іске асыру. Тек объективті және жан-жақты талдау негізінде шағын қалалардың әлеуметтік-экономикалық тарихы, олардың экономикасы мен әлеуметтік-мәдени саласының инфрақұрылымын қалыптасу тарихын зерделей отырып қана келешегін айқындауға мүмкіндік туады. Өткен Кеңестік кезеңдегі Шығыс Қазақстандағы шағын қалалардың дамуын мұндай тарихи талдау шағын қалалардағы қазіргі күрделі әлеуметтік-экономикалық мәдени жағдайдың тамыры мен бастауын көруге мүмкіндік береді.

Шығыс Қазақстандағы шағын қалалар мен олардың тұрғындарының тарихын зерделеу аймақтың қазіргі заманғы барлық әлеуметтік-экономикалық, мәдени және басқа да проблемаларын шешумен тығыз байланысты. Бүгінгі таңда Шығыс Қазақстандағы шағын қалалар ел экономикасы мен әлеуметтік саласының ең ауыр нүктелерін білдіреді және олардың тарихын зерттемей, әлеуметтік-экономикалық даму проблемаларын талдаусыз бүкіл аймақтың болашақ дамуын болжау мүмкін емес деп айтуға болады.

Пайдаланылган ддебиеттер тізімі:

1. Моногорода Казахстана: методические основы оценки состояния и направления развития/ Под. ред. Н.К.Нурлановой. - Алмать:: Институт экономики КН МОН РК. -2014.С. 30.

2. Казахстан - самые маленькие города по площзади территории //tochka-na-karte.ru- 1 c.

3. Казахская ССР. Краткая энщиклопедия в 4-х т., Т.2. Алиа-Ата: Гл. ред. Казах, сов. энщиклопедии, 1988, $608 c$.

4. Аягөз [Мәтін] : Шызыс Қазақстан обльлсы, Аягөз ауданының энщиклопедиясы. Т. 1 / суретші: Б. Серікбай, И. Серікбаева. - Алматы: Көркем, 2010. - 676 б.

5. Казахстан - самые маленькие города по площуади территории //tochka-na-karte.ru- 1 c.

6. Шызыс Қазақстан облысыныңңң мұраваттықық қызметі.Өлкетану

http://www.arhiv.vko.gov.kz/region_07.htm(14.02.2012). //https://adebiportal.kz/kz/ultbolmysy/view/65

7. Итоги Всесоюзной переписи населения 1959года. КазССР. -М.: Гостатиздат, 1962. - 200 c. - C. 17.1 , c. 16

8. Кочианов А.К., Айдарханов МХ. Малье города при переходе к рынку (проблемы и приоритеты). -Алматы: Ғылыми, - 115 c.

9. Юрицын В. Большие проблемы мальх городов. //Новости недели. - 2002. - №22. - 5-11 июня.

10. Чуланова 3. Проблемы развития малых агропромышленных городов Казахстана. //Аль Пари. - 2002.№2-3. - C. 27.

List of references:

1. Monogorod of Kazakhstan: methodological foundations of assessment of the state and directions of Development/ Sub. Ed. "I Don't Know," I Said. - Almaty: Institute of economics of the Republic of Kazakhstan. -2014. P. 30.

2. Kazakhstan - the smallest cities on the territory //tochka-na-karte.ru -1 p.

3. Kazakh SSR. Kratkaya encyclopedia in 4-X Vol., Vol. 2. Alma-Ata: GL. Ed. "No," I said. encyclopedia, 1988, 608 $P$.

4. Ayagoz [text]: encyclopedia of Ayagoz District, East Kazakhstan region. Vol. 1 / artist: B. Serikbay, I.

Serikbayeva. - Almaty: Art, 2010. - 676 P.

5. Kazakhstan - the smallest cities on the territory //tochka-na-karte.ru -1 p.

6.archival service of the East Kazakhstan region.Local history -

http://www.arhiv.vko.gov.kz/region_07.htm(14.02.2012). //https://adebiportal.kz/kz/ultbolmysy/view/65

7. the results of the all-important migration of the population in 1959. Kazssr. Moscow: Gostatizdat publ., 1962. -

200 P. - P.17.1, p. 16

8. Koshanov A. K., AIDARKHANOV MH. Small cities when moving to the market (problems and priorities). -

Almaty: Science, - 115C.

9. Yuritsyn V. big problems of small cities. //News of the week. - 2002. - No. 22. - June 5-11.

10. Chulanova Z. problems of development of small agricultural cities of Kazakhstan. // Al Paris. - 2002. - No. 2-3. p. 27. 